\title{
STRATEGI PEMASARAN WAYANG KAMPUNG SEBELAH
}

\author{
Setyabudhi Rahardjo Situmorang \\ setyabudhi.situmorang@gmail.com
}

\begin{abstract}
Wayang Kampung Sebelah (WKS) is one of the phenomenal new genre shadow puppet art show group in today's society and was favored by many people. Their performance in its innovation and creativity of the puppet art show implicates on the marketing methods developed, which results to attracting public attention to the work. The purpose of this study is to determine why WKS was favored among audiences, the marketing methods used and challenges faced in making innovations in a puppet show by WKS. The theory underlying this study refers to the concept of segmentation covering segmentation, targeting and positioning (STP). The study used qualitative research methods. Data analysis was performed based on the theory of marketing strategy with case study approach using a single instrument type with three interviewees. The results showed that the ability of the WKS puppeteer in storytelling and communicating with the audience was a skill difficult to imitate as it was a talent possessed by someone individually thus to attract the audience dissolved in the story told. WKS marketing strategy on the segmentation stage was done using the geographical segmentation by promoting the performance on village societies, which in its development all ages and education eventually become audiences of the group's performances. At the targeting stage, WKS do not choose specifically which consumers is targeted in marketing because the guidelines that are held by WKS, which is that the puppet show should be able to be enjoyed by all people. While on positioning stage, WKS has successfully positioned itself as a puppet group with a unique and hard to imitate style although the idea of the show refers to the style of many traditional puppet show that had long been abandoned. WKS implemented four price levels in the effort to market their work which were as follows: the village attack, subsidized performance attack, public commercial and the professionals commercial. Challenges in creating works comes a lot more from internal factors, which is maintaining the creation spirit of the group, while from external factors there are no significant obstacles but requires a long enough time for WKS to be accepted by the intellectuals (academic society).
\end{abstract}

Keywords: WKS, dalang, marketing strategy (segmentation, targeting, positioning)

\section{Pendahuluan}

Hingga kini seni pewayangan masih ada dan tetap dipelihara dengan baik pakempakemnya. Namun seiring dengan banyaknya pilihan hiburan, lambat laun wayang menjadi lebih banyak ditonton oleh kalangan usia dewasa dan orang tua. Kalangan remaja lebih banyak mengikuti hiburan dari luar, misalnya Korean Dance Style (Sulistyobudi, 2014: 127). Hiburan 
wayang yang sarat dengan filosofi menjadikan wayang pernah menjadi media bagi penyebaran agama di Indonesia yang berarti bahwa wayang pernah menjadi tontonan yang sangat populer pada masanya sehingga merupakan media yang baik bagi para penyebar agama (Nurgiyantoro, 2011: 24).

Persaingan dengan berbagai hiburan dari Barat telah melahirkan upaya-upaya perubahan terhadap seni pewayangan dengan tujuan untuk melestarikannya. Berbagai inovasi yang telah dilakukan oleh para pelaku seni tersebut adalah untuk menyesuaikan dengan keadaan masyarakat sekarang. Salah satu contoh dari upaya tersebut adalah lahirnya Wayang Kampung Sebelah (WKS) pada tahun 2001. Wayang Kampung Sebelah didirikan oleh Ki Jlitheng Suparman (dalang WKS) yang mengusung cerita-cerita dengan tema kritik sosial.

Pertunjukan Wayang Kampung Sebelah (WKS) merupakan pertunjukan wayang genre baru yang dianggap memiliki pakem di luar pakem pewayangan (Solopos 28 Februari 2004 dan Republika 12 Maret 2003), yang oleh Sosiawan Leak (personel WKS) disebut sebagai pakem baru (Solopos, 9 September 2001). Pertunjukan WKS juga dianggap menjungkirbalikkan konsep filosofi wayang tradisional karena tidak bercerita seputar dunia raja, melainkan mengangkat permasalahan rakyat biasa (Bengawan Pos, 18 Agustus 2001). Selain itu ada juga kritikan bahwa alur cerita pertunjukan WKS tidak disampaikan secara runtut (Kompas, 3 Januari 2001).

Meskipun pertunjukan WKS dianggap keluar dari pakem pewayangan, namun hingga saat ini WKS banyak digemari oleh berbagai kalangan masyarakat. Beberapa tokoh seni bahkan memuji pertunjukan WKS sebagai wayang yang cerdas (Ki Enthus dalam Saudagar edisi September 2006), komunikatif dalam penyajiannya dan dapat mengikuti dinamika di masyarakat (Cak Idin dalam Saudagar edisi September 2006), dan cerita dalam pertunjukan sangat realistis (Frida Amartani dalam Saudagar edisi September 2006).

Tokoh dalam pementasan WKS seperti tokoh dalam masyarakat kampung yang plural, terdiri dari penarik becak, bakul jamu, preman, pelacur, pak RT, pak lurah, hingga pejabat negara. Wayang yang terbuat dari kulit bergambar manusia ini berbeda dengan tokoh-tokoh dalam Wayang Purwa yang berasal dari kisah Ramayana dan Mahabarata. Nama karakter di WKS di antaranya Kampret, Karyo, Lurah Somad, Eyang Sidik Wacono, Hansip Sodron, Silvy, dan tokoh penghibur lain seperti Roma Ra Mari-Mari, Inul Darah Tinggi, Cak Dul dan lainnya.

Selain strategi penokohan dalam pertunjukan wayangnya yang berpijak pada kekinian, WKS juga mendasari suasana pertunjukannya dengan musik kontemporer. Melalui seperangkat alat band yang memainkan musik-musik pop, campursari bahkan jazz. Musikmusik yang dimainkan oleh WKS memberikan suasana santai dan situasi masa kini. Hal ini dibuktikan dalam penelitian Situmorang (2014), tentang inovasi musik pengiring pada pertunjukan wayang kulit dalam strategi pemasaran seni pertunjukan. Situmorang, dalam penelitiannya terhadap inovasi musik pengiring oleh WKS, menemukan bahwa adopsi masyarakat terhadap pertunjukan WKS menunjukkan adanya kehati-hatian WKS dalam menciptakan nilai konsumen dan mengelola relasi dengan audiens. Banyak tantangan yang 
dihadapi oleh sebuah organisasi seni di dalam mendorong calon audiens mereka untuk mau mengadopsi inovasi seni yang ditawarkan kepada mereka.

Selain inovasi yang telah disebutkan di atas, Wayang Kampung Sebelah (WKS) juga banyak mengubah kebiasaan dalam pagelaran wayang seperti posisi penonton yang boleh ikut naik di atas panggung dan boleh ikut menimpali percakapan dalang, serta jarak panggung yang dekat dengan penonton (yang pada pertunjukan wayang biasanya berjarak jauh untuk memberi ruang pada penari). Namun ada dua hal yang tidak ingin diubah dan tetap dipertahankan oleh WKS, yaitu ukuran layar dan pakaian yang sederhana (tidak menonjol, meskipun di wayang tradisional sekarang seringkali pakaian justru terlalu mencolok).

Unsur bahasa dan musik dalam pertunjukan Wayang Kampung Sebelah (WKS) merupakan dua faktor yang mampu menggiring penonton datang karena kedua faktor tersebut dominan mempengaruhi suasana panggung, karena semua orang mampu mengerti dialog dalam pertunjukannya (yang biasanya memakai bahasa Jawa kuno) dan atmosfer suasana digiring oleh musik yang akrab di telinga orang-orang pada zaman ini. Pertunjukan WKS secara fisik tidak berbeda pertunjukan wayang tradisional sehingga tetap mempertontonkan keunikan tradisional pewayangan namun dengan atmosfer berbeda yang tidak asing bagi penonton masa kini yaitu melalui bahasa yang dipergunakan dan musik yang dimainkannya.

Banyak tantangan yang dihadapi oleh sebuah organisasi seni di dalam mendorong calon audiens mereka untuk mau mengadopsi inovasi seni yang ditawarkan kepada mereka. Situmorang (2014), dalam penelitiannya terhadap inovasi musik pengiring oleh WKS, menemukan bahwa adopsi masyarakat terhadap pertunjukan WKS yang menunjukkan adanya kehati-hatian WKS dalam menciptakan nilai konsumen dan dalam mengelola relasi dengan audiensi.

Selain menyadari bahwa sebuah inovasi membutuhkan sosialisasi, Wayang Kampung Sebelah (WKS) juga menyadari bahwa harga sebuah pementasan wayang tidak sedikit sehingga menerapkan strategi pemasaran dengan membagi harga berdasarkan pihak-pihak yang ingin mengundang mereka, menjadi 4 kelompok: : (1) serangan pentas, yaitu bermain secara gratis ke desa-desa tanpa harus diundang, (2) serangan pentas bersubsidi, yaitu pentas atas permintaan kelompok-kelompok sosial seperti Karang Taruna atau mahasiswa dengan dana operasional yang minim dari pihak pengundang, (3) komersial publik, yaitu pentas secara komersial dengan harga yang tidak mahal karena diperuntukkan bagi acara-acara pribadi (perorangan) seperti: hajatan, pernikahan atau khitanan, dan (4) komersial profesional, yaitu pentas pada acara-acara perusahaan seperti MNCTV, BCA dan kopi „Kapal Apiee yang pernah mengundang WKS dengan harga yang relatif tinggi (Situmorang, 2014).

Wayang Kampung Sebelah (WKS) merupakan kelompok seni yang bukan berorientasi pada bisnis industri namun telah berhasil menarik minat banyak kalangan masyarakat untuk menontonnya. Pertunjukan WKS banyak ditonton oleh berbagai lapisan masyarakat, usia para penonton pertunjukan bukan hanya para orang tua namun sudah merambah kepada usia muda. Keunikan yang ada di dalam pertunjukan WKS pernah menarik minat stasiun televisi MNCTV 
untuk menyiarkan pertunjukannya setiap Sabtu malam, menjadi indikator potensi bisnis. Pada 2014 yang lalu WKS berhasil menjual 50 episode pertunjukan wayang kepada pihak MNCTV.

Perjalanan kelompok Wayang Kampung Sebelah (WKS) tidak dapat dipisahkan dari kelompok Wayang Kampung, yang merupakan cikal bakal terbentuknya WKS. Wayang Kampung lahir pada awalnya hanya sebagai karya seni rupa pada 1992, yang setahun kemudian sempat digarap bersama Bengkel Muda Surabaya. Di akhir 2000 ide ini dikembangkan oleh komunitas seniman muda Solo (Kompas, 3 Januari 2001).

Ketika wayang genre baru seperti Wayang Kampung Sebelah (WKS) muncul, masyarakat yang dulunya banyak meninggalkan pertunjukan wayang tradisional karena begitu banyak muncul hiburan jenis baru terutama di televisi, kembali melirik pertunjukan wayang sebagai sesuatu yang ternyata masih menarik di zaman modern. Hal ini menunjukkan bahwa masyarakat terhibur melalui pertunjukan wayang ini. Fenomena ini sejalan dengan teori pemasaran yang dinyatakan oleh Kotler dan Keller (2012: 5) yaitu pemasaran adalah tentang mengidentifikasi dan memenuhi kebutuhan manusia dan sosial. Salah satu definisi terpendek yang baik dari pemasaran adalah "terpenuhinya kebutuhan secara menguntungkan." Pemenuhan kebutuhan oleh masing-masing pihak ini disebabkan oleh adanya pertemuan dalam kegiatan pemasaran, yang oleh Blythe (2005: 2) disebut sebagai kegiatan-kegiatan yang muncul pada pertemuan antara organisasi dengan pelanggannya.

Cara pendekatan kelompok Wayang Kampung Sebelah (WKS) dalam berhubungan dengan penonton pertunjukannya, menunjukkan sebuah komunikasi dua arah yang terjalin yang menunjukkan kekuatan pertunjukan WKS justru bertolak dari respons audiens di dalam pertunjukan itu sendiri, seperti komentar yang spontan dilontarkan oleh audiens. Cara seperti ini seiring dengan pendapat Berstein (2007: 17) tentang cara berpikir organisasi yang memastikan organisasi bekerja sama dengan pelanggan untuk menciptakan, menyampaikan, dan berbagi nilai. Menurut Bernstein, mind-set pada pemasaran tradisional adalah sebuah pendekatan secara perintah dan kontrol, yang mengandalkan penjualan kepada pelanggan pasif yang tuntutan dan persepsinya dipercaya dapat dipengaruhi dan dimanipulasi.

Pendapat Bernstein (2007) di atas sejalan dengan pendapat Webster (1997), bahwa organisasi yang sukses di masa depan akan berfokus pada pelanggan, dan bukan pada produk atau teknologi, yang didukung oleh kompetensi informasi pasar yang menghubungkan suara pelanggan dengan semua proses penyampaian nilai milik perusahaan. Organisasi pemasaran yang sukses akan memiliki keterampilan yang diperlukan untuk mengelola banyak proses pemasaran strategis (Webster, dalam Hooley et al, 2008: 3), yang berarti bahwa pemasaran yang baik bukanlah suatu kebetulan, tetapi merupakan hasil dari perencanaan yang matang, dan eksekusi dengan menggunakan alat dan teknik terkini (Kotler dan Keller, 2012: 3). Demikian halnya juga dengan pertunjukan WKS yang merancang setiap pertunjukannya dengan menyesuaikan pada kehidupan masa kini lewat cerita-ceritanya yang mengusung cerita dengan tema kritik sosial dan tokoh-tokohnya yang merupakan gambaran masyarakat kampung masa kini yang plural, serta lewat dukungan cara pemasaran terkini melalui internet terutama lewat Youtube dan penggunaan fanpage di sosial media Facebook. Menurut Byrnes 
(2009: 347), organisasi seni yang tidak memiliki halaman website MySpace atau Facebook atau klip video yang ditampilkan di YouTube memiliki risiko jauh dari mata publik, meskipun bukan berarti bahwa situs website yang paling up-to-date pasti menarik bagi seseorang untuk selalu menonton sebuah konser.

Hubungan antara seni dan pasar adalah sesuatu yang kompleks, yang berarti bahwa pemasar seni perlu memperhatikan berbagai masalah yang mungkin tidak muncul dengan cara yang sama, atau ke tingkat yang sama, dalam pemasaran produk konvensional (Parsons dan MacLaren, 2009: 55). Oleh sebab itu, sebuah organisasi perlu secara sistematis mempelajari kebutuhan dan keinginan, persepsi dan sikap, preferensi dan kepuasan dari pelanggan (Bernstein, 2007: 17). Hal ini tersirat dalam pertunjukan WKS yang penuh dengan berbagai modifikasi di atas panggung seperti jarak menonton, lokasi duduk penonton dan sebagainya, dengan tujuan memberikan kenyamanan dan kepuasan bagi penonton. Bernstein juga menjelaskan bahwa kekuatan seorang manajer pemasaran didapatkan dari pengetahuannya tentang pelanggan. Hal-hal berikut didapatkan melalui pemasaran, yaitu: perihal si pelanggan, nilai si pelanggan bagi organisasi, dan cara menciptakan nilai lebih bagi pelanggan. Organisasi kemudian harus bertindak atas dasar informasi ini dengan meningkatkan penawaran untuk lebih memenuhi kebutuhan pelanggan. Kotler bahkan menempatkan urusan dengan pelanggan pada urutan teratas dalam daftar "Sepuluh Kesalahan Fatale-nya jika mengabaikan perihal pelanggan, yang berarti bahwa hubungan baik dengan pelanggan adalah yang paling utama (Kotler, 2004: 10).

Jangkauan penonton pertunjukan Wayang Kampung Sebelah (WKS) yang luas, jika melihat pada umur penonton (anak-anak hingga dewasa) dan pendidikannya (pendidikan rendah hingga perguruan tinggi) menunjukkan bahwa segmen penonton yang dibidik oleh WKS adalah cukup luas. Gagasan konvensional dari strategi pemasaran adalah membayangkan pemasar melakukan segmentasi terhadap penonton, membidik beberapa atau semua segmen tersebut dan kemudian memposisikan penawaran dengan cara yang memberikannya keuntungan di dalam persaingan (Parsons dan MacLaren, 2009: 65).

Menurut Parson dan MacLaren lebih lanjut (2009: 65-66), seorang pemasar seni harus menjadi seorang ahli situasi, dalam arti bahwa ia memperhitungkan jangkauan yang luas dari faktor-faktor segmenting, targeting dan positioning ketika merumuskan strategi pemasaran seni. Parsons \& MacLaren menyatakan bahwa pemasar seni, perlu memperhitungkan berbagai jangkauan luas dari faktor-faktor ketika merumuskan strategi pemasaran seni. Ini termasuk peran organisasi atau artis dalam rantai nilai yang relevan; konvensi artistik dan ideologi yang secara historis berlaku; tingkat, sifat dan tingkat inovasi artistik; sumber pendanaan yang tersedia dan persyaratan dan prioritas yang mereka bawa bersama mereka; lokasi pemasar di dalam struktur proyek seni dan kekuatan pemasar atau kekurangannya; daya penerimaan konsumen, penggemar dan kritikus; jenis model bisnis yang layak di sektor seni yang relevan; ketegangan antara seni dan perdagangan; dan pengaruh kebijakan pemerintah, perkembangan teknologi, media dan ekonomi, dan seterusnya. 
Penonton pertunjukan WKS yang terdiri atas berbagai umur dan pendidikan, menunjukkan kemampuan WKS menyatukan berbagai segmen pasar di dalam sebuah pertunjukannya terlihat dari kesuksesan WKS mendapatkan kesempatan mempertunjukkan pementasannya di MNC TV setiap Sabtu dan Minggu malam pada 2014. Konsep segmentasi pertama kali dikembangkan oleh Smith pada 1957, dengan tujuan untuk mengidentifikasi sekelompok orang yang memiliki kebutuhan yang dapat dipenuhi oleh satu produk tunggal, dalam rangka untuk mengkonsentrasikan upaya perusahaan pemasaran secara paling efektif dan ekonomis. Segmentasi pasar digambarkan sebagai cara kita sebagai pemasar membagi pasar ke dalam kelompok pelanggan yang sama, di mana ada perbedaan penting antara kelompok-kelompok tersebut (Hooley et al, 2008: 206). Segmentasi yang paling umum digunakan adalah berdasarkan: geografi, psikografi, perilaku dan demografi (Blythe, 2005: 7578).

Proses segmentasi terdiri atas tiga unsur utama, yaitu: segmentation, targeting dan positioning (Kotler, 1988 dalam Dibb dan Simkin, 1991: 4). Gambar 1 memberikan gambaran dari unsur-unsur ini. Proses segmentation ini oleh Wilson dan Giligan (2005) dalam Khan (2013: 56) dijabarkan dalam lima fase, yaitu: fase analisis situasi, fase segmentasi pasar, fase pembidikan pasar, fase memposisikan produk dan fase bauran pemasaran.

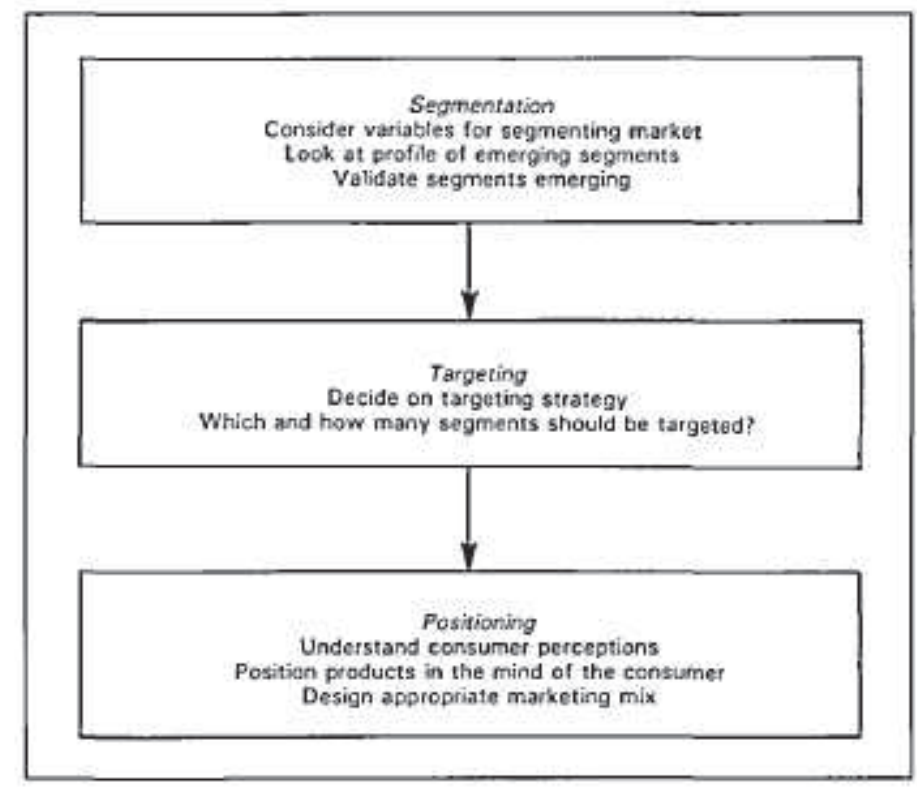

FIGURE 1.

The Basic Elements of Segmentation

Gambar 1. Elemen Dasar dari Segmentasi

(Sumber: Dibb dan Simkin, 1991: 5) 
Segmentasi pasar selalu berfungsi sebagai dasar untuk orientasi pelanggan dan diferensiasi (Haley, 1988 dalam Bose, 2012: 115). Segmentasi membantu organisasi untuk menentukan kelompok pelanggan dan membantu membentuk kelompok produk atau jasa tertentu. Dengan cara itu ia membantu banyak hal dalam membangun kegiatan rantai nilai tertentu untuk kelompok tertentu dan karena itu menciptakan sinkronisasi yang indah pada pemeliharaan rantai nilai dalam organisasi untuk setiap sasaran segmen (Hunt dan Arnett, 2004 dalam Bose, 2012: 115).

Konsumen sebuah produk atau layanan yang ada, bukanlah kelompok yang homogen dan merupakan sebuah kenyataan bahwa setiap konsumen memiliki kebutuhan individu, preferensi, sumber daya dan perilaku unik tersendiri (Matzler dan Hinterhuber, 1998 dalam Bose, 2012: 115). Masalah yang dihadapi oleh produsen adalah bahwa merupakan sesuatu yang benar-benar mustahil untuk menyediakan berbagai jenis barang untuk konsumen yang berbeda. Oleh karena itu mereka mengelompokkan pasar ke dalam kelompok yang homogen dan segmentasi adalah cara yang paling layak untuk melakukannya (McDonald dan Dunbar, 2004 dalam Bose, 2012: 115).

Instrumen strategi pemasaran seperti segmenting dan targeting bisa memberi keuntungan bagi lembaga pertunjukan seni dan membuat tawaran mereka lebih kompetitif (Zuzana et al., 2012: 92). Pembagian pasar menjadi segmen-segmen yang lebih kecil ini, terjadi misal karena perbedaan kebutuhan, karakteristik, atau perilaku yang mungkin membutuhkan secara terpisah strategi pemasaran atau bauran (Kotler dan Armstrong, 2011: 190). Tujuan dari segmentasi adalah konsentrasi pada energi dan kekuatan pemasaran terhadap pengelompokan untuk mendapatkan keuntungan kompetitif dalam segmen tersebut. Konsentrasi ini adalah inti dari semua strategi pemasaran dan segmentasi pasar adalah alat konseptual untuk membantu pemasar untuk mencapai fokus ini (Goyat, 2011: 45).

Goyat (2011: 53) menemukan dalam studi literaturnya bahwa a). Pemilihan dasar segmentasi pasar sangat tergantung pada industri dan jenis produk itu sendiri dan b). Secara kritis dapat dinyatakan bahwa demografi dapat terbukti menjadi dasar yang baik untuk segmentasi tapi semuanya tergantung pada jiwa konsumen. Berbeda dengan Goyat, Barry dan Weinstein (2009: 315) dalam studi literaturnya menyebutkan bahwa pemasar telah menyadari bahwa geodemografi jarang memberikan perspektif yang memadai tentang pasar yang kompleks saat ini. Sebaliknya, segmentasi psikografis telah mengungkapkan wawasan target pasar yang lebih kuat sekaligus memberikan pemasar batu loncatan untuk beradaptasi dengan proposisi penjualan dan penyusunan bauran pemasaran.

Kesuksesan pertunjukan Wayang Kampung Sebelah (WKS) dari waktu ke waktu telah menunjukkan bahwa pertunjukannya sudah melekat dalam benak para konsumen (penonton). Inilah yang disebut sebagai positioning, yaitu tindakan merancang penawaran dan citra perusahaan sehingga mereka menduduki posisi kompetitif yang berarti dan berbeda dalam benak target pelanggan (Kotler, 1997 dalam Hooley et al, 2008: 205). Dalam istilah Kotler dan Armstrong (2011: 207): diilustrasikan dengan produk dibuat di pabrik-pabrik (dalam hal ini proses pembuatan pertunjukan), namun merek berada di benak konsumen (dalam hal ini 
penonton). Sedangkan arti dari differentiation adalah strategi menciptakan sesuatu yang dipandang unik di pasar. Dengan strategi ini, kekuatan dan keterampilan perusahaan digunakan untuk membedakan penawaran perusahaan dari para pesaingnya mengikuti beberapa kriteria yang dihargai oleh konsumen (Hooley et al, 2008: 49).

Positioning juga berkaitan dengan posisi pemasar di antara para pesaing sejenis. Dalam pandangan Hooley et al (2008:205), hal ini berkaitan dengan bagaimana pelanggan memandang alternatif penawaran di pasar, dibandingkan dengan yang lainnya. Senada dengan pendapat tersebut, Blythe (2005: 87) mendefinisikan positioning sebagai: posisi produk di pasar dilihat melalui kacamata suatu kelompok pelanggan di mana kelompok pelanggan tersebut dikenal sebagai segmen sasaran dari pasar. Positioning menunjukkan keberadaaan suatu produk atau menunjukkan suatu produk yang akan dipasarkan, diletakkan di dalam pasar oleh para pelanggan. Positioning merupakan pengembangan dari citra produk secara langsung terhadap produk pesaing dan produk lainnya yang dilakukan oleh perusahaan bersangkutan. Tujuannya adalah memberikan perhatian manajemen oleh penerima terhadap produk tertentu dan untuk membedakan produk tersebut yang didukung perusahaan, dibandingkan dengan produk sejenis (Tek, 1999 dalam Karadeniz, 2009: 98).

Pelanggan, penonton, atau konsumen dari produk (seni) adalah pengguna akhir yang disebut sebagai target pasar. Target pasar ini juga mencakup penyandang dana dan sponsor. Oleh karena itu pemasar seni juga perlu mempertimbangkan bagaimana cara mereka mengakses dana dan sponsorship (Versfeld, 2012: 24). Tidak semua pertunjukan seni menggantungkan pendanaan melalui penjualan tiket, seperti halnya kelompok Wayang Kampung Sebelah (WKS). Sudah menjadi kebiasaan bahwa pertunjukan wayang tradisional di-"tanggap" oleh pihak yang membutuhkan jasa kelompok pertunjukan wayang, dan kebiasaan ini juga dipakai oleh WKS. Pihak yang memakai jasa pertunjukan wayang ini di dunia Barat dikenal sebagai donatur atau sponsor, meskipun di Jawa maknanya berbeda. Menurut Versfeld, upaya yang diarahkan untuk mengamankan keuangan melalui pendanaan dan sponsorship ini juga didorong secara strategis melalui upaya pemasaran. Menurut Anderton (2011: 155) dalam penelitiannya terhadap sponsor perusahaan di sektor festival musik kontemporer sejak 1960, setiap kesuksesan even festival yang berkesan bagi pengunjung, membuat sponsor berharap ini akan diwujudkan menjadi pangsa pasar, reputasi dan penjualan, sementara penyelenggara berharap bahwa itu akan mendorong kehadiran ulang di masa depan.

Pelanggan adalah fondasi dalam bisnis dan yang menjaga agar bisnis tersebut tetap eksis (David, 2011: 51). Menurut David, apa yang dipikirkan oleh sebuah bisnis tentang apa yang ia produksi bukan lagi menjadi yang terpenting, khususnya tidak untuk masa depan bisnis dan kesuksesannya. Apa yang pelanggan pikir tentang apa yang ia beli, apa yang ia anggap bernilai, adalah yang menentukan dalam hal ini menentukan apa itu bisnis, apa yang diproduksi, dan apakah itu akan berhasil. Hal yang sama dikemukakan oleh Abfalter dan Mirski dalam jurnalnya, bahwa para audiens seni merupakan pemangku kepentingan utama untuk setiap organisasi seni, sebagaimana penyediaan dan akses kepada budaya merupakan 
salah satu tujuan politik utama yang melegitimasi pendanaan publik. Kebutuhan untuk menghasilkan pendapatan dari penjualan tiket dan layanan lainnya menambahkan poin ini (Abfalter dan Mirski, 2005: 4).

Strategi pemasaran yang berorientasi pada pelanggan dapat digambarkan seperti pada Gambar 2. Peran dari pemasaran yang ditampilkan pada Gambar 2, merangkum kegiatankegiatan utama yang terlibat dalam pengelolaan strategi pemasaran yang customer-driven dan bauran pemasaran (Kotler dan Armstrong, 2012: 48).

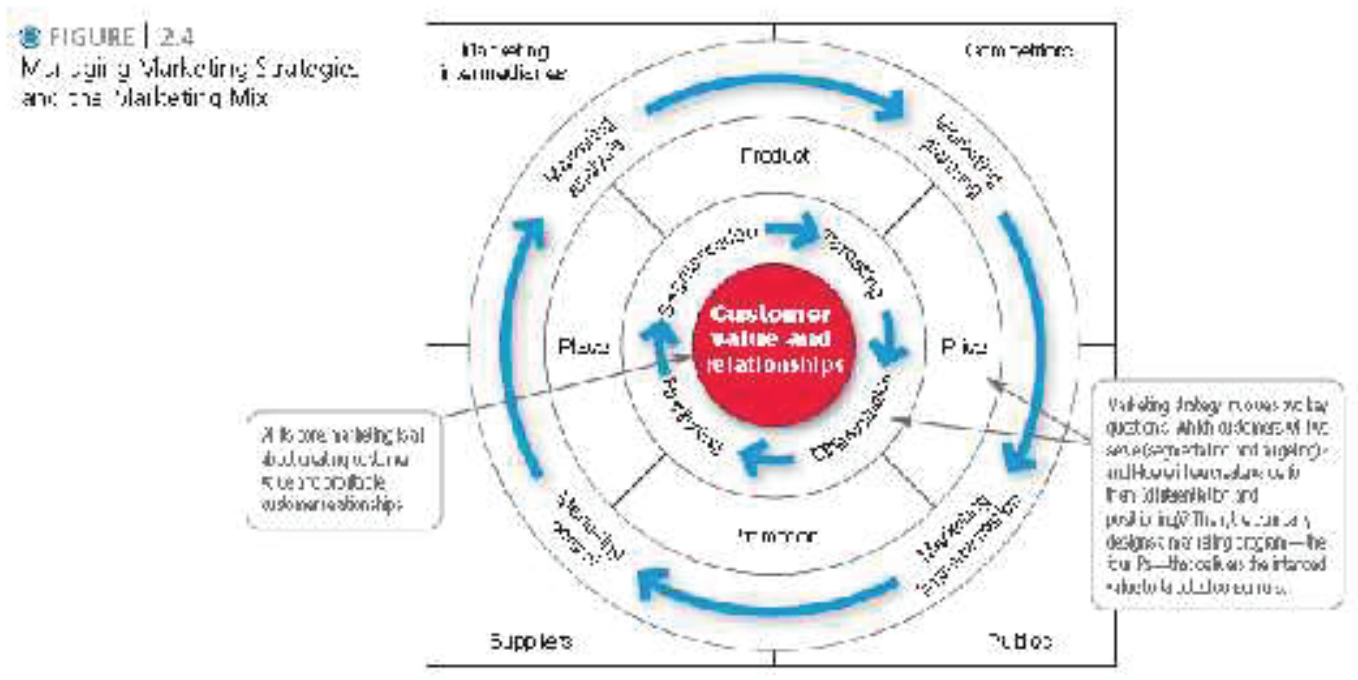

Gambar 2. Pengelolaan Strategi Pemasaran dan Bauran Pemasaran (Sumber: Kotler dan Armstrong, 2012: 48)

Pada Gambar 2, terlihat konsumen berada di titik paling tengah, sebagai sasaran utamanya, yaitu untuk menciptakan nilai bagi pelanggan dan membangun hubungan dengan pelanggan yang menguntungkan. Kemudian perusahaan memutuskan mana pelanggan yang akan dilayani (segmentation dan targeting) dan bagaimana melayaninya (differentiation dan positioning). Setelah perusahaan mengidentifikasi pasar keseluruhan maka kemudian akan membagi menjadi segmen yang lebih kecil, kemudian memilih segmen yang paling menjanjikan, dan berfokus pada melayani dan memuaskan pelanggan di segmen ini. Strategi pemasaran memandu perusahaan untuk mendisain suatu bauran pemasaran yang terpadu yang terdiri atas faktor-faktor yang dikendalikannya yaitu: produk, harga, tempat, dan promosi (4P). Proses yang digambarkan Kotler dan Armstrong ini menggambarkan apa yang dilakukan secara umum oleh kebanyakan organisasi termasuk juga Wayang Kampung Sebelah (WKS).

Model bauran pemasaran 4-P berguna bila diterapkan pada perusahaan manufaktur dan pemasaran produk-produk fisik, namun karena adanya peningkatan ketersediaan layanan, model di atas (4-P) tidak memberikan gambaran yang cukup lengkap sehingga pada tahun 1981 Boom dan Bitner mengusulkan kerangka kerja 7-P untuk memasukkan faktor-faktor tambahan yaitu: orang, proses dan bukti fisik. Setiap organisasi akan cenderung memiliki 
pendekatan yang berbeda terhadap bauran pemasaran, dan karena itu tidak akan ada dua perusahaan yang akan mengikuti pendekatan pemasaran yang sama persis (Blythe, 2005: 9).

Konsumen membuat keputusan mereka berdasarkan sejumlah informasi, apakah itu iklan yang mereka lihat di surat kabar atau gosip yang mereka dengar dari seorang teman. Perilaku dari konsumen merupakan proses yang berkelanjutan dan karena semua konsumen hidup dalam masyarakat dan berada dalam kontak dengan orang lain dalam satu atau lain cara, maka orang lain juga mempengaruhi mereka (Nikula, 2012: 23). Secara umum, perilaku konsumen merujuk pada perilaku yang diungkapkan oleh konsumen dalam mencari, membeli, menggunakan, mengevaluasi, dan membuang produk dan layanan yang mereka harapkan akan memuaskan kebutuhan mereka (Schiffman dan Kanouk, 1994:7).

Kedatangan audiens menonton sebuah pertunjukan langsung (live performances) berkaitan erat dengan strategi pemasaran sebuah pertunjukan dan penilaian calon audiens terhadap promosi, jika belum mengenal reputasi si artis atau sebuah kelompok seni (Bernstein, 2007:8). Ciceo dan Andreea (2012: 1119) dalam penelitiannya di Romania menyebutkan bahwa alasan utama mengapa orang menghadiri acara seni pertunjukan live utamanya adalah karena kebutuhan sosial dan harga diri mereka. Namun keputusan pembelian tiket adalah sesuatu yang kolektif di mana dalam sebuah kelompok ada perannya masing-masing orang seperti mengajak, meyakinkan dan membeli tiket (Ciceo dan Andreea, 2012: 1124-1125). Penelitian Ciceo dan Andrea ini berkaitan erat dengan keberhasilan WKS dalam melakukan promosi di desa-desa yang melibatkan peran promosi dari mulut ke mulut.

Sehubungan dengan hal tersebut di atas, pemasar seni harus pertama kali mempertimbangkan apa manfaat yang konsumen dapatkan dari pengalaman artistik yang ditawarkan. Mengetahui manfaat apa yang dicari oleh berbagai kelompok konsumen, adalah mungkin untuk menargetkan segmen tertentu dengan penawaran khusus (Zuzana et al, 2012: 101-102). Penelitian Zuzana et al ini adalah mengenai pengembangan alternatif segmentasi yang berbeda dari yang biasa dipakai secara tradisional (segmentasi berdasarkan kelas sosial) yaitu berdasarkan motivasi khusus penonton sehingga mau menghadiri pertunjukan.

Berbeda dengan penelitian di atas, Park dan Chang (2010: 6) meneliti tentang segmentasi konsumen seni pertunjukan live dihubungkan dengan kesediaan (kebiasaan) menonton di negara (bagian) lain. Konsumen yang diteliti adalah penonton penggemar berat yang meliputi 30\% populasi konsumen. Park dan Chang menemukan bahwa segmen yang paling dominan dalam menonton dan menyumbangkan dana serta sering menonton di negara (bagian) lain adalah konsumen berpendidikan di atas sarjana dan menjadi anggota organisasi seni. Mereka mayoritas adalah wanita di atas 45 tahun.

Secara tidak langsung setiap strategi yang dilakukan oleh Wayang Kampung Sebelah (WKS) berkaitan dengan kompetisi memperebutkan pasar audiens. Saat ini di dalam dunia bisnis yang sangat kompetitif, setiap badan usaha berjuang untuk mendapatkan supremasi atas pihak lain dan beberapa berhasil memperolehnya. Hal ini ditegaskan dalam penelitian Bose (2012:113-114) dalam penelitian kualitatif studi literatur yang mendalam terhadap kontribusi segmentasi pasar dan strategi fokus pelanggan dalam membangun rantai nilai efektif. Temuan 
menunjukkan bahwa segmentasi pasar membantu organisasi untuk mengsegmentasi seluruh pasar dengan cara yang efektif dan dengan demikian sangat membantu dalam menghasilkan produk dan layanan yang dapat didiversifikasi dan disesuaikan. Pada sisi yang lain strategi fokus pelanggan juga membantu perusahaan dengan baik untuk fokus pada pelanggan tertentu dan membuat rantai nilai dari pasar yang efektif dan customer driven. Segmentasi pasar dan strategi fokus pelanggan merupakan dua senjata tajam yang dapat memberikan kontribusi mendalam untuk memastikan pertumbuhan yang luas dan cepat.

Sejumlah asumsi mendasari analisis ekonomi terhadap pilihan konsumen. Pertama, karena pendapatan mereka terbatas, konsumen tidak mampu untuk memenuhi semua keinginan material mereka. Oleh karena itu mereka harus memilih di antara banyak kemungkinan objek untuk dikonsumsi. Kedua, pilihan ini dibuat secara rasional. Konsumen mencoba untuk menghabiskan pendapatan mereka dengan cara dengan maksud untuk mendapatkan kemungkinan total kepuasan terbesar darinya. Ekonom menggunakan istilah "utility" sebagai pengganti istilah "satisfaction," sehingga dalam jargon ekonomi, konsumen berperilaku sebagai "utility maximizers" (Heilbrun dan Gray, 2009:61). Ketika konsumen membuat keputusan, mereka biasanya memanfaatkan informasi yang sudah tersimpan dari dalam memori mereka. Informasi ini cenderung terstruktur dan terorganisir menggunakan asosiasi berbagai potongan informasi dan memungkinkan konsumen untuk memanggil kembali informasi ini ketika diminta. Hal ini memiliki dampak langsung pada pengambilan keputusan konsumen (Haydn, 2009: 106).

Makin banyaknya penggemar wayang yang dianggap oleh sebagian besar seniman sebagai pertunjukan inovatif dan kreatif, berimplikasi pada metode pemasaran yang dikembangkan oleh Wayang Kampung Sebelah (WKS). Namun terlepas dari itu, usaha mensosialisasikan pertunjukan WKS merupakan perjuangan tersendiri lewat pertunjukan gratis dari desa ke desa hingga jangkauan penonton WKS semakin meluas ketika mereka lebih sering pentas di kota lewat berbagai tawaran pentas maupun kerjasama. Usaha pemasaran yang dilakukan lewat empat jenis strategi pembagian harga, merupakan langkah unik yang membantu proses adopsi inovasi pertunjukan mereka kepada masyarakat dan sekaligus merupakan sasaran dari segmentasi yang dibidik oleh WKS. Tujuan dari penelitian terhadap WKS ini adalah: (1) Untuk mengetahui alasan WKS mampu menjadi kelompok wayang yang sangat digemari oleh banyak kalangan meskipun memiliki pakem pertunjukan yang berbeda dengan wayang tradisional, (2) Untuk mengetahui metode pemasaran yang digunakan oleh WKS, dan (3) Untuk mengetahui tantangan dalam melakukan inovasi pertunjukan wayang.

\section{Metode Penelitian}

Metode penelitian yang digunakan pada penelitian ini adalah metode penelitian kualitatif dan menggunakan pendekatan studi kasus tipe instrumen tunggal. Metode kualitatif dipilih karena jenis data yang diperoleh membutuhkan interpretasi terhadap konsep maupun teori 
yang relevan dengan penelitian ini. Sedangkan pendekatan studi kasus tipe instrumen tunggal (single instrumental case study) dipilih karena penelitian ini dilatarbelakangi oleh fenomena yang terjadi pada salah satu kelompok seni pertunjukan yaitu kelompok seni Wayang Kampung Sebelah (WKS).

Fenomena yang terjadi adalah WKS merupakan kelompok wayang baru yang cukup fenomenal di masyarakat dan digemari oleh banyak kalangan. Namun oleh beberapa orang, pertunjukan WKS dianggap melanggar pakem pewayangan. Peneliti menyimpulkan bahwa fenomena ini berhubungan dengan strategi pemasaran yang dikembangkan oleh WKS yang meskipun dianggap melanggar pakem pewayangan tapi mampu menarik perhatian banyak kalangan untuk mengadopsi dan terus menonton pertunjukannya.

Adopsi adalah keputusan individu untuk menjadi pengguna tetap sebuah produk dan diikuti oleh proses loyalitas konsumen. Proses consumer-adoption ini merupakan sebuah langkah mental yang dilewati seorang individu mulai dari saat pertama kali mendengarkan adanya sebuah inovasi hingga adopsi final (Kotler dan Keller, 2012: 589). Fenomena consumer-adoption inilah yang mendasari peneliti untuk memilih pendekatan studi kasus. Dalam sebuah penelitian studi kasus, sebuah fenomena dipilih di antara fenomena lainnya dan dipelajari secara mendalam, berbeda dengan penelitian lain di mana peneliti mengumpulkan data dari banyak unit atau kasus dan kemudian mencari pola-pola umum di dalam angka (Neuman, 2007: 20). Melalui fenomena ini juga maka berbagai pertanyaan penelitian muncul sehingga penelitian dilakukan untuk menjawab fenomena tersebut.

Berdasarkan hal tersebut, pada penelitian ini, peneliti mengkaji dan menganalisis lebih dalam metode pemasaran yang digunakan oleh WKS yang meliputi segmenting, targeting, differentiation dan positioning. Fase segmenting dikaji lebih dalam untuk mengetahui kejelian WKS di dalam mengelompokkan penonton, yang berfokus pada penonton dan bukan pada produk atau teknologi semata. Fase targeting dikaji untuk mengetahui kejelian WKS dalam melakukan pemilihan segmen (pemilihan penonton) yang tepat. Differentiation terkait dengan strategi WKS dalam menciptakan produk seni pertunjukan yang dipandang unik di pasar sehingga menarik banyak kalangan untuk menonton pertunjukan mereka dan positioning terkait dengan bagaimana WKS memposisikan produk yang dipasarkan mereka supaya tetap membekas dalam benak konsumen (penonton) mereka sehingga berdampak pada bagaimana pelanggan memandang penawaran dari WKS, dibandingkan dengan produk pertunjukan lain yang dipasarkan. Dengan kata lain positioning berkaitan dengan posisi WKS di antara para pesaing sejenis di mata pelanggan (penonton).

Untuk mengetahui strategi pemasaran yang diterapkan oleh WKS, peneliti melakukan wawancara dengan mempersiapkan beberapa pertanyaan untuk dijadikan bahan data/ sumber yang relevan dalam penelitian ini. Data yang diperoleh selanjutnya diintepretasikan secara logis berdasarkan konsep atau teori yang relevan dengan penelitian ini.

Sumber data pada penelitian ini adalah data primer dan data sekunder. Data primer diperoleh dari wawancara tidak terstruktur yang dilakukan pada tanggal 21 Maret 2014. Kemudian dilakukan wawancara tidak terstruktur lagi pada Oktober 2015 dan Mei tahun 2016. 
Data sekunder diperoleh dari berbagai literatur pada text book, jurnal ilmiah, disertasi serta data hasil rekaman pertunjukkan Wayang Kampung Sebelah (WKS).

Informan penelitian dipilih berdasarkan kajian terhadap fenomena yang terjadi, sehingga dipilih Ki Jliteng Suparman sebagai narasumber primer. Berdasarkan hasil wawancara pertama dengan Ki Jliteng Suparman tentang inovasi musik yang dilakukan oleh WKS, peneliti menemukan ada inovasi lain dan strategi pemasaran yang dikembangkan dan diterapkan oleh WKS sehingga membuat WKS menjadi terkenal dan digemari banyak kalangan. Berdasarkan data yang diperoleh dari wawancara pertama dengan Ki Jliteng Suparman, maka peneliti memandang perlu untuk dilakukan wawancara lanjutan dengan sumber informan lainnya sehingga dapat menggali dan menganalisis informasi lebih dalam lagi tentang WKS. Oleh sebab itu ditentukan dua informan/ narasumber lain pada penelitian ini yaitu Bapak Yayat Suheryatna (YS) sebagai narasumber kedua (sekunder) dan narasumber ketiga (tersier) adalah Ki Catur Benyek Kuncoro (CB).

Teknik pengumpulan data yang digunakan dalam penelitian ini adalah teknik wawancara dan pengkajian dokumen. Peneliti juga ikut berpartisipasi sebagai penonton dalam pementasan wayang WKS yang berlangsung mulai Februari 2014 (melalui siaran MNCTV) dan tanggal 19 September 2015 di Universitas Atmajaya Yogyakarta. Melalui proses ini, peneliti dapat melihat, mengetahui, memahami dan mengkaji lebih dalam tentang segmenting, targeting, positioning dan differentiation dalam strategi pemasaran yang digunakan oleh WKS.

Tahap analisis penulis berdasarkan pada Miles \& Huberman (Denzin \& Lincoln, 2005: 447-457). Analisis data penelitian ini dilakukan dalam 3 tahapan yang berlangsung saat proses pengambilan data, yaitu (1) Reduksi data; berdasarkan sumber data yang diperoleh, data tersebut direduksi atau dikelompokkan dalam beberapa kategori sambil melakukan pengkodean, (2) Penyajian data; merupakan hasil reduksi data yang disajikan secara naratif. Penyajian data dipaparkan dalam bentuk uraian berdasarkan aspek-aspek yang muncul, (3) Penarikan kesimpulan dan verifikasi; pada tahapan ini, penafsiran data dilakukan berdasarkan kerangka teori tentang konsep segmenting, targeting, positioning dan differentiation dalam strategi pemasaran yang digunakan oleh WKS dengan tujuan akhir membuat kesimpulan penelitian.

\section{Hasil dan Pembahasan}

Perubahan merupakan sebuah kewajaran dalam kehidupan manusia, dan alam. Perubahan dalam sebuah pertunjukan dari waktu ke waktu adalah sesuatu yang sering dialami namun sering pula diabaikan karena manusia sering berkeinginan mempertahankan keadaan (status quo). Pertunjukan wayang sebenarnya telah mengalami perubahan yang besar dari waktu ke waktu. Sejak zaman Kerajaan Mataram sebelum masuknya agama Islam, perubahan di dalam pertunjukan wayang sebenarnya sudah terjadi sehingga bukan merupakan sesuatu yang harus dipersoalkan. Perubahan yang dilakukan oleh nenek moyang kita terhadap wayang merupakan perubahan menuju sebuah penguatan eksistensi. 
Perubahan di dalam sebuah pertunjukan adalah hal yang baik selama perubahan tersebut tidak menjauhkannya dengan penonton, perasaan penonton yang merasa tidak menyatu dengan pertunjukannya juga jauhnya penonton dari lokasi panggung (yang sering terjadi dalam pertunjukan wayang saat ini). Hal ini sebenarnya bukan ide baru, namun sebuah ide yang sudah ditinggalkan oleh para dalang saat ini yang mengklaim sebagai dalang tradisional dan berpegang teguh pada pakem yang dianggap benar.

Di setiap pertunjukan Wayang Kampung Sebelah (WKS) selain mengutamakan kedekatan dengan penontonnya, penonton juga diberi keleluasaan untuk memilih tempat di mana ia ingin duduk. Hal ini terkait dengan kesukaan sudut pandang tiap individu ke layar. Terutama anak-anak sering dipersilakan naik di atas panggung. Suasana seperti ini sangat kontras dengan pertunjukan wayang pada umumnya. Alasan mendekatkan jarak duduk antara penonton dengan layar adalah untuk membangun kedekatan dalang dengan penonton, karena jauhnya jarak akan memutus komunikasi antara dalang dengan penonton.

Selain perlakuan terhadap penonton seperti di atas, kekuatan cerita (Jawa: lakon) juga merupakan unsur yang membawa kedekatan dengan penonton, dan ini sangat disadari oleh WKS. Banyaknya pertunjukan wayang yang tidak mengutamakan kekuatan cerita inilah yang menyebabkan wayang tradisional banyak ditinggalkan oleh masyarakat karena hanya sekedar mengulang cerita, sehingga sering faktor-faktor di luar cerita lebih ditonjolkan untuk menarik perhatian penonton. Kejelian WKS menggarap cerita dapat dilihat dari keseriusan penggarapan cerita yang sesuai dengan tema yang akan diangkat, sehingga WKS sering dipakai untuk mengisi acara-acara yang bersifat sosialisasi kepada masyarakat. Pengaruh wawasan yang luas dan pengetahuan tentang Wayang Purwa dari dalang WKS yang juga lulusan ilmu sastra memberikan bobot tersendiri bagi terciptanya lakon-lakon yang dibuat. Cerita dan terutama pembawa cerita (dalang) merupakan kekuatan utama WKS yang mampu membuat penonton tetap duduk menonton pertunjukannya hingga selesai.

Perhatian WKS pada penonton dan cerita sangat dijunjung tinggi dengan berbagai cara yang menghindarkan penonton terhilang fokusnya terhadap cerita. Berbeda dengan banyak kelompok pertunjukan wayang yang lebih fokus pada kemegahan panggung seperti: penabuh gamelan dengan gamelannya yang berwarna kuning emas mengkilat serta penyanyi wanita2 cantik yang menghadap penonton dan layar yang melebihi ukuran standar, WKS dengan berbagai caranya lebih memfokuskan pada layar sehingga penonton tidak akan terganggu perhatiannya. Penabuh gamelan dan penyanyi wanita dalam pertunjukan WKS turut menghadap ke layar seperti halnya dalang WKS.

Pakem memang sering dipermasalahkan jika ada inovasi baru muncul, meskipun sebenarnya permasalahan tentang pakem bukan muncul dari para penikmat pertunjukan itu sendiri, artinya sebagian besar masyarakat penonton tidak pernah mempermasalahkan adanya kebaruan dalam mengusung sebuah pertunjukan. Hal ini disebabkan karena seni pertunjukan merupakan sesuatu yang hidup dan pasti akan berubah, sehingga kebaruan-kebaruan yang muncul adalah hal biasa. Sesuatu yang baru atau inovasi memang membutuhkan waktu untuk diterima atau diakui keberadaannya. Hal ini terjadi pula pada WKS. 
Kekuatan panggung WKS terletak pada komunikasinya dengan para penontonnya. Hal ini menurut Abfalter (2005: 4) mempengaruhi reputasi sebuah lembaga seni yang sangat tergantung pada kepuasan penonton dan reaksi mereka terhadap pertunjukannya. Reputasi ini memiliki daya tarik bagi para sponsor, baik personal, lembaga pemerintah maupun perusahaan bisnis. Reaksi penonton pertunjukan WKS terhadap pertunjukannya, tidak terlepas dari sang dalang yang memiliki kharisma dalam menyampaikan sebuah lakon. Ini merupakan kekuatan WKS yang sangat sulit ditiru oleh kelompok wayang lain. Reaksi penonton dalam pertunjukan WKS ini sangat jarang ditemui dalam pertunjukan wayang lain, karena reaksi penonton berupa celetukan mengenai tokoh-tokoh wayang kepada dalang merupakan sesuatu yang dianggap tabu pada pertunjukan wayang tradisional. Suasana dalam pertunjukan WKS ini menyebabkan penonton merasa nyaman dalam menonton pertunjukan tersebut karena merasa ikut andil dalam sebuah pertunjukan.

Pertunjukan WKS sangat berbeda jika kita terbiasa menonton pertunjukan wayang tradisional, karena secara fisik maupun suasana sangat berbeda. Namun ketika kita menonton pertunjukannya, kita masih memiliki persepsi bahwa pertunjukan tersebut merupakan pertunjukan wayang, hanya berbeda. Salah satu ciri yang paling utama, yang menyebabkan pertunjukan WKS dianggap sebagai wayang adalah adanya kelir (layar). Weiss (2006: 6) menyatakan bahwa perubahan di bidang teknologi telah membantu perkembangan pertunjukan wayang serta penyebarannya. Tradisi Jawa, bagaimanapun, tampaknya memungkinkan pelapisan sebuah pertunjukan baru ke dalam tradisi yang lebih tua dari pertunjukan wayang tanpa menghilangkan yang lama karenanya, mengakibatkan kemungkinan pertunjukan baru ke dalam tradisi yang lebih tua tanpa memusnahan mereka dan mengakibatkan munculnya beberapa bentuk-bentuk hibrida yang banyak dan kontemporer. Suasana pertunjukan WKS sangat berbeda ketika musik yang mengiringi pertunjukan wayang bukan gamelan Jawa melainkan seperangkat alat musik zaman sekarang. Pada musik pengiring pertunjukan WKS yang menggunakan seperangkat alat band, musiknya telah memberikan nuansa yang sangat berbeda. Suasana pertunjukan wayang yang dulunya anggun dan sakral menjadi santai dan tidak formal serta sangat akrab dengan suasana zaman sekarang (Situmorang, 2014: 31).

Komunikasi bagi WKS merupakan kunci utama di dalam kesuksesan pertunjukannya. Komunikasi ini berlaku baik kepada penonton maupun sponsor (tuan rumah pertunjukannya). Komunikasi yang baik bertujuan untuk menjalin hubungan yang baik pula.

Hubungan yang baik dengan para penontonnya di atas panggung terlihat dari respons penonton ketika pertunjukan berlangsung. Ketika terjadi reaksi celetukan penonton terhadap dalangnya, maka dari situ terlihat bagaimana antusiasme penonton terhadap cerita yang disampaikan oleh dalang. Seringkali hal ini menjadi sebuah kehebohan tersendiri di dalam setiap pertunjukan WKS. Namun hal ini justeru yang diinginkan oleh WKS, dan konsep ini merupakan konsep lama, bukan sebuah ide baru yang diciptakan oleh WKS.

Selain menjalin komunikasi yang erat dengan penontonnya, WKS juga berusaha menjalin hubungan baik dengan para sponsor tuan rumah pertunjukan. Cara WKS melakukan ini adalah dengan menerapkan biaya yang berbeda sesuai tingkatan kemampuan sponsor. WKS 
membaginya menjadi empat tingkatan, yaitu (1) Serangan Pentas, WKS tidak memungut biaya atas pertunjukan mereka, bersifat spontanitas memilih desa tertentu sebagai sasaran pertunjukan; (2) Serangan Pentas Bersubsidi, khusus bagi kelompok-kelompok sosial seperti Karang Taruna atau mahasiswa, mereka hanya dikenakan dana operasional yang kecil (50\%); (3) Komersial Publik, harga komersial yang diperuntukkan bagi acara-acara pribadi (perseorangan) seperti hajatan, pernikahan atau khitanan, dengan harga yang murah; (4) Komersial Profesional, jika WKS tampil pada acara-acara perusahaan seperti MNCTV, BCA dan kopi 'Kapal Api' yang pernah mengundang WKS dengan harga yang relatif tinggi (Situmorang, 2014: 33).

Gaya komunikasi dan menjaga relasi ini sesuai dengan konsep Relationship Marketing, yaitu berfokus pada nilai 'seumur hidup' dari pelanggan (Blythe, 2005: 6). Relationship Marketing tidak bersifat transaksional sesaat, namun membina hubungan baik untuk transaksi selanjutnya yang berkelanjutan (Copulsky et al, 1990; Blythe, 2005).

Menurut Copulsky et al. (1990: 17, 20), lewat relationship marketing, hubungan pemasaran menjadi suatu bentuk komunikasi personal, yang mampu melintasi batas-batas sebelumnya antara iklan umum, promosi penjualan, pemasaran langsung, dan hubungan masyarakat. Copulsky et al. berpendapat bahwa relationship marketing menyediakan akses bagi pengiklan kepada suatu alat yang lebih kaya untuk membangun brand image dan kesadaran serta pengeluaran biaya promosi yang lebih efektif.

Kegiatan WKS melakukan pertunjukan gratis berkeliling desa mewujudkan relationship marketing yang melintasi kegiatan pengiklanan, promosi, pemasaran langsung dan hubungan masyarakat seperti pernyataan Copulsky et al. Promosi lewat kegiatan ini menunjukkan efek yang lebih besar dibanding lewat media koran. Hal ini dikarenakan pengaruh dari word-ofmouth (WOM) dari penonton yang menyebarkan rasa puas atau tidak puas mereka terhadap pertunjukan WKS. Hal ini seiring dengan teori Ciceo dan Andreea (2012) yang menyatakan bahwa keputusan untuk membeli tiket adalah sesuatu yang kolektif di mana dalam sebuah kelompok ada perannya masing-masing orang seperti mengajak, meyakinkan dan membeli tiket.

Setiap organisasi membutuhkan dana untuk dapat menggerakkan setiap operasi yang telah direncanakan baik itu organisasi profit maupun non-profit. Dana yang didapatkan oleh organisasi seni bisa didapatkan dari pemerintah ataupun swasta, juga melalui penjualan tiket atau suvenir dan lain sebagainya. Mengatur keuangan sebuah organisasi tidaklah mudah, banyak faktor seperti kepemimpinan dan faktor dukungan pemerintah dan sebagainya bisa membuat perbedaan dalam membesarkan sebuah organisasi.

Ketika berhadapan dengan budaya pendanaan, seni pertunjukan dikaitkan dengan „Baumol cost disease (dijelaskan oleh Baumol dan Bowen pada tahun 1960), yang menyatakan bahwa seni pertunjukan memiliki masalah kronis karena kemungkinan keterbatasannya meningkatkan pendapatan dan mengurangi biaya produksi.5Permasalahan mengenai pendapatan dan produksi merupakan hal yang masih sedikit tertutup di dunia seni pewayangan. Dalang menjadi penerima pendapatan terbesarpendapatan sesuai nilai kontrak 
dengan pihak pengundang, sementara pekerja lain seperti pengrawit dan pesinden tidak pernah mengalami kenaikan pendapatan. Hal ini wajar jika melihat dalang sebagai pihak pemberi pekerjaan dan penyedia semua fasilitas seperti gamelan dan tempat latihan.

Terobosan yang dibuat oleh WKS untuk lebih mensejahterakan semua komponen kelompok di luar dalang, seperti pesinden dan pengrawit dilakukan dengan sistem pemberian poin kepada masing-masing anggota kelompok sesuai tingkatan peran masing-masing anggota di dalam kelompok WKS. Poin ini akan dikalikan dengan nilai standar upah mereka, sehingga dengan begitu upah yang mereka terima akan menyesuaikan dengan besarnya pendapatan WKS yang artinya upah mereka sama seperti dalang dalam arti menyesuaikan dengan pemasukan sesuai nilai kontrak. Hal ini berbeda jika dibandingkan dengan sistem pada kelompok pewayangan tradisional pada umumnya.

\section{Kesimpulan}

[1] Penyebab pertunjukan kelompok Wayang Kampung Sebelah (WKS) digemari oleh banyak kalangan adalah gaya bercerita dan berkomunikasi yang disampaikan oleh dalang WKS. Kemampuan dalang WKS bercerita dan berkomunikasi tentang fenomena kehidupan di masyarakat merupakan kemampuan yang susah ditiru karena merupakan talenta yang dimiliki oleh seseorang secara individual. Dengan bahasa yang sederhana dan menarik, dalang WKS mampu membuat penonton larut dalam cerita yang disampaikan.

[2] Strategi pemasaran yang diterapkan WKS mengacu pada konsep segmenting, targeting, dan positioning (STP). Pada tahap segmenting adalah secara geografis karena dalam mempromosikan pertunjukan mereka dilakukan terhadap masyarakat di desa, yang dalam perkembangannya semua kalangan usia dan pendidikan akhirnya menjadi penonton pertunjukan kelompok ini. Pada tahap targeting, WKS tidak memilih secara khusus segment mana yang akan dibidik dikarenakan pedoman yang dipegang WKS adalah wayang harus bisa dinikmati oleh semua kalangan. Sedangkan pada tahap positioning WKS telah berhasil memosisikan diri sebagai kelompok wayang yang unik dan susah ditiru oleh kelompok wayang lainnya meski idenya banyak yang mengacu pada gaya pertunjukan wayang tradisional yang telah lama ditinggalkan. Selain itu, dalam memasarkan produk pertunjukan mereka, WKS menerapkan empat tingkatan harga meliputi serangan desa, serang pentas bersubsidi, komersial publik dan komersial profesional yang tidak dilakukan oleh kelompok wayang lainnya.

[3] Tantangan WKS dalam melakukan inovasi pertunjukan lebih banyak berasal dari faktor internal dalam hal mempertahankan semangat berkarya kelompok. Sedangkan faktor eksternal tidak menjadi hambatan yang berarti namun butuh waktu yang lama bagi WKS untuk dapat diterima oleh kalangan intelektual (akademis). 


\section{Kepustakaan}

Abfalter, D. E. \& Mirski, P. J. 2005. Perceived Success in the Arts, Paper presented at the 8th International Conference on Arts \& Cultural Management (AIMAC), Montréal.

Anderton, C. 2011. Music festival sponsorship: between commerce and carnival. Arts Marketing: An International Journal, Vol. 1 Iss. 2 pp. 145 - 158, ISSN: 2044-2084, DOI: 10.1108/20442081111180368.

Barry, J. \& Weinstein, A. 2009. Business psychographics revisited: from segmentation theory to successful marketing practice, JOURNAL OF MARKETING MANAGEMENT, Vol. 25, No. 3-4, pp. 315-340 ISSN0267-257X print /ISSN1472-1376 online (C) Westburn Publishers Ltd.

Bernstein, J. S. 2007. Arts Marketing Insights: the dynamics of building and retaining performing arts audiences, Jossey-Bass, San Fransisco, CA, USA.

Blythe, J. 2005. Essentials of Marketing, Third Edition, Pearson Education Limited, England.

Bose, T. K. 2012. Market Segmentation and Customer Focus Strategies and Their Contribution Towards Effective Value Chain Management. International Journal of Marketing Studies, Vol. 4, No. 3; June 2012, DOI:10.5539/ijms.v4n3p113.

Byrnes, W. J. 2009. Management and the Arts. Fourth Edition, Elsevier Inc., United Kingdom.

Ciceo \& Andreea. 2012. Attending Live Performing Arts Experiences. Why And How Is The Decision Taken?, Annals of Faculty of Economics 1(1), ISSN: 1119-1126.

Copulsky, J. R. \& Wolf, M. J. 1990. Relationship Marketing: Positioning for the Future. Journal of Business Strategy, Vol. 11, Iss 4, pp. 16-20, DOI: 10.1108/eb060069.

David, F. R. 2011. Strategic management: concepts and cases, Pearson Education, Inc., USA.

Dibb, S \& Simkin L. 1991. Targeting, Segments and Positioning. International Journal of Retail \& Distribution Management, Vol. 19 No. 3, pp. 4-10, MCB University Press, ISSN: 09590552, DOI: $10.1108 / 09590559110143800$.

Denzin, N. K. \& Lincoln, Y. S (editor). 2005. The SAGE Handbook Of Qualitative Reaserch. Third Edition, Sage Publications Inc., USA.

Doran, A. 2016. Public Funding and Private Fundraising in the Performing Arts, The Problematic Case of the Teatro alla Scala. ASK (Arts, Science, Knowledge) Centre, Università Commerciale Luigi Bocconi, Milan, Italy, diakses pada www.medeu.org/documents/MED4/Dossier3/DORAN.pdf tanggal 23 Juni 2016.

Goyat, S. 2011. The basis of market segmentation: a critical review of literatur. European Journal of Business and Management, ISSN 2222-1905 (Paper) ISSN 2222-2839 (Online) Vol 3, No.9, 2011.

Haydn, N. 2009. Basics Marketing: Consumer Behaviour, AVA Publishing SA, Switzerland.

Heilbrun, J. \& Gray, C. M. 2004. The Economics of Arts and Culture. Second Edition, Cambridge University Press, UK.

Hooley, G. J., Piercy, N. F. \& Nicoulaud, B. 2008. Marketing Strategy and Competitive Positioning. Fourth Edition, Pearson Education Limited, England.

Karadeniz, M. 2009. Product Positioning Strategy in Marketing Management. Journal of Naval Science and Engineering, Vol. 5, No 2, pp. 98-110. 
Khan, T. 2013. STP strategy for New Product Launch: A Work in Progress. International Journal of Business and Management Invention, Volume 2 Issue 3 || March. 2013\| PP.5665, ISSN (Online): 2319 - 8028, ISSN (Print): 2319 - 801X.

Kotler, P. 1988. Marketing Management: Analysis, Planning and Control. Prentice-Hall, Englewood Cliffs, New Jersey.

Kotler, P. \& Armstrong, G. 2012. Principles of marketing -- 14th ed. Prentice Hall, USA.

Kotler, P. \& Keller, K. L. 2012. Marketing Management. 14th edition, Prentice Hall, USA.

Kotler, P. 2004. Ten Deadly Marketing Signs: Signs and Solutions. John Wiley \& Sons, Hoboken, New Jersy, USA.

Neuman, W. L. 2007. Basics of Sosial Research: Qualitative and Quantitative Approaches, Second Edition, Pearson Education, Inc., USA.

Nikula dan Sanna-Maria. 2012. Quantitative Surveys vs. Behavioural Analysis Studying Audiences Case, Espoo Ciné International Film Festival 2010 /Sanna-Maria, SibeliusAkatemia, Helsinki.

Nurgiyantoro, B. 2011. Wayang dan Pengembangan Karakter Bangsa, Jurnal Pendidikan Karakter, Tahun I No. 1 Oktober 2011, ISSN: 2089-5003.

Parson, E. \& MacLaran, P. 2009. Contemporary Issues in Marketing and Consumer Behaviour. Elsevier Ltd., USA.

Park, S. H. \& Chang, H. 2010. An Analysis of the Performing Arts Consumer: Developing market segments by using CHAID, (July 30, 2010). International CHRIE ConferenceRefereed Track, University of Massachusetts - Amherst.

Schiffman, L. G. \& Leslie L.K. 1994. Consumer Behaviour. Fifth Edition, Prentice Hall Inc., USA.

Situmorang, S. R. 2014. The Innovation of Accompanist Music of Wayang Kulit (Leather Puppet) Performance in Performing Art Marketing Strategy. Journal of Asean Research of Arts and Design, Volume 1 no. 1,ISSN 2351-0684, Thailand.

Soedarsono. Wayang Kulit: A Javanese Shadow Theatre. East Asian Cultural Studies, vol. XV, Nos. 1-4, March 1976.

Sulistyobudi, N. 2014. Budaya Wayang: Kelestarian dan Tantangannya Ke Depan. Jantra, Jurnal Sejarah dan Budaya, Vol. 9, No. 2, Desember 2014, ISSN 1907 - 9605.

Versfeld, S. (editor). 2012. Arts Marketing Toolkit, ARTerial Network, South Africa.

Weiss, S. 2006. Listening To An Earlier Java: Aesthetics, gender, and the music of wayang in Central Java, KITLV Press, Koninklijk Instituut voor Taal-, Land- en Volkenkunde (Royal Netherlands Institute of Southeast Asian and Caribbean Studies), Netherlands, ISBN-10 90 6718273 7, ISBN-139789067182737.

Zuzana, C., Jitka, Č., \& Miroslav, K. 2012. Segmenting the Performing Arts Markets: The Case of Czech National Theater Attenders' Motivations. Journal of Competitiveness, Vol.4, Issue 3, pp.92-104, ISSN: 1804-171X (print), ISSN: 1804-1728 (on-line), DOI: 10.7441/joc2012.03.07, Tomas Bata University. 